\title{
Lean Management Implementation at Municipal Level: Opportunities, Conditions, Barriers
}

\author{
A.Ya. Minakova ${ }^{1, *}$ and E.N. Koroleva ${ }^{1}$ \\ "Corresponding author: anminakowa@ mail.ru \\ ${ }^{1}$ Samara State University of Economics, Samara, Russia
}

\begin{abstract}
The use of new management technologies that have shown their efficiency in the business sector is essential in municipal areas while developing an innovative economy in Russia. The study is aimed at grounding the conditions of using lean management technologies aiming at increasing efficiency of municipal management in Russia. The research was aimed at and solved three main objectives: 1) the systematization of 'lean production' technologies and instruments suitable to use at the municipal level; 2) the analysis of foreign and domestic experience of using lean management by governments and local authorities; 3) the formulation of conditions for successful adoption of lean management by local authorities and the identification of barriers to its implementation at the municipal level in Russia. The study is based on the systemic approach viewing lean management as an integrated system including regulatory and legal provisions, theoretical and methodological research carried out by foreign and domestic scholars, best practices of implementing lean production technologies and instruments. The results of the study are aimed at local authorities introducing innovative technologies designed to improve the efficiency of municipal management.
\end{abstract}

Keywords: lean production, municipal lean management, innovation, technology, efficiency, waste.

\section{Introduction}

In the current context, Russia has to face the necessity to adopt innovative development which involves implementing a complex of innovations at each level of national economy management. However, the municipal level has been on the outside of these processes so far. That has resulted in a low municipal efficiency [1]. In this regard, this sector implies the introduction of new management technologies that have shown their efficiency in the business sector. Businesses have acquired great experience in using technologies and instruments providing benefits in terms of competitiveness through productivity gains and cost-cutting in the production of goods and services. They are based on 'lean management' principles [2].

\section{Problem Statement}

Invented by John Krafcik, the term 'Lean production' was used by the group of scholars of the Massachusetts Institute of Technology while studying the Toyota company production system [3]. This concept accounts for significantly more than the production and management system of a single company. In a broad sense, lean production is a managerial concept based on customer-orientation and elimination of waste [4].

Lean production principles were first used in public sector in Great Britain in 2001, and since 2002 spread to the USA. Lean management is used by the governments in Canada, Sweden, Australia and other countries [5]. The use of lean technologies made the work of government and municipal bodies more efficient, increasing the quality of public services and managing budget restrictions.

Currently, only some Russian municipalities have implemented the principles of lean management. However, though the experience of lean management implementation by municipal bodies outstrips theoretical research; there are no lean technologies adapted to the municipal level.

\section{Research Questions}

The research was aimed at three main objectives:

1) The systematization of 'lean production' technologies and instruments suitable to use at the municipal level;

2) The analysis of foreign and domestic experience of using lean management by governments and local authorities;

3) The formulation of conditions for successful adoption of lean management by local authorities and the identification of barriers to its implementation at the municipal level in Russia. 


\section{Purpose of the Study}

The research is aimed at finding the opportunities for the use of lean production technologies to increase the efficiency of municipal management.

The study is aimed at finding out the conditions for the successful realization of lean management technologies at the municipal level. These technologies are viewed as managerial innovations designed to improve the efficiency of municipal management in Russia.

\section{Research Methods}

The objectives of the research were reached at the basis of the systemic approach where lean management is considered as the whole including a complexity of interrelated elements, among them: regulatory and legal provisions, theoretical and methodological research carried out by foreign and domestic scholars, best practices of implementing lean production technologies and instruments, the results obtained in this sphere. The methods of logical, structural and functional, comparative analyses were also used.

\section{Findings}

Lean management differentiates between two types of activities - value adding and non value adding ones. Value adding activities are necessary for creating goods or services. Non value adding activities could be divided into necessary ones needed to accomplish value adding activities and unnecessary ones not contributing to value. The efficiency of a process is a proportion of time cycle spent on value adding activities. Waste becomes central to this concept. Waste is any resources used that does not create any value for a customer [6]. Table 1 shows causes and characteristics of main waste kinds in the framework of lean management.

Table 1. Causes and characteristics of main waste kinds in lean management

\begin{tabular}{|l|l|l|}
\hline \multicolumn{1}{|c|}{ Causes } & \multicolumn{1}{|c|}{ Characteristics } & \multicolumn{1}{c|}{ Examples } \\
\cline { 2 - 4 } Overproduction & $\begin{array}{l}\text { More parts or products are } \\
\text { produced }\end{array}$ & $\begin{array}{l}\text { Excessive document copies, unnecessary } \\
\text { reports }\end{array}$ \\
\hline Wefects & $\begin{array}{l}\text { Defect production, correction of } \\
\text { errors }\end{array}$ & $\begin{array}{l}\text { Defected services, errors in data input, } \\
\text { documents or information loss }\end{array}$ \\
\hline Moving & $\begin{array}{l}\text { Inaction connected with } \\
\text { paperwork or decision-making }\end{array}$ & $\begin{array}{l}\text { Waiting for signature, idle working time, } \\
\text { dependence for other employees, problems } \\
\text { with software }\end{array}$ \\
\hline Excess Processing & $\begin{array}{l}\text { Any transportation which is not } \\
\text { necessary }\end{array}$ & $\begin{array}{l}\text { Sending of unnecessary documents, } \\
\text { reposted documents }\end{array}$ \\
\hline Motion & $\begin{array}{l}\text { Any transportation not adding } \\
\text { value } \\
\text { Secondary data reports and information, } \\
\text { repeated editing of documents }\end{array}$ & $\begin{array}{l}\text { Excessive walking, transfer of documents } \\
\text { by hand, searching files and documents }\end{array}$ \\
\hline Inventory & $\begin{array}{l}\text { Any quantity of a product } \\
\text { exceeding the minimum needed } \\
\text { for production }\end{array}$ & $\begin{array}{l}\text { Obsolete documents, obsolete equipment, } \\
\text { purchases 'for later on' }\end{array}$ \\
\hline Non-Utilized Talent & $\begin{array}{l}\text { Management fails to fully } \\
\text { utilize employee time and talent }\end{array}$ & $\begin{array}{l}\text { Non-utilized talents, ideas and suggestions, } \\
\text { unequal distribution of activities, lack of } \\
\text { motivation }\end{array}$ \\
\hline
\end{tabular}

Source: compiled by the authors.

The following elements are distinguished within lean production: strategic management, processes and personnel [7]. The appropriate technologies and instruments of lean production are applied to them (see Table 2).

Table 2. The main technologies and instruments of lean production

\begin{tabular}{|l|l|}
\hline Technology or instrument & \multicolumn{1}{|c|}{ Main features } \\
\hline Kaizen & $\begin{array}{l}\text { Gradual and continuous improvements by all employees aimed at } \\
\text { increasing quality and reducing loss }\end{array}$ \\
\hline $5 \mathrm{~S}+1$ & $\begin{array}{l}\text { The organization of working space }-5 \text { steps to improve a } \\
\text { workplace organization }\end{array}$ \\
\hline Mapping & $\begin{array}{l}\text { The map of a current and an ideal process enabling to find } \\
\text { opportunities for improving processes }\end{array}$ \\
\hline Gemba & $\begin{array}{l}\text { Physical observation of the process when employees can find problems } \\
\text { and losses allowing them to develop skills of finding out and solving } \\
\text { the problems in the working environment }\end{array}$ \\
\hline
\end{tabular}




\begin{tabular}{|c|c|}
\hline Poka-yoke & $\begin{array}{l}\text { Prevention from unintentional mistakes by using organizational and } \\
\text { engineering techniques allowing to accomplish an operation only in } \\
\text { a correct way }\end{array}$ \\
\hline Just-in-time & $\begin{array}{l}\text { A managerial approach aimed at reducing inventories in } \\
\text { accordance with a productional chart, with necessary resources } \\
\text { coming in the numbers required, at the precise place and time }\end{array}$ \\
\hline «5 Whys» & The analysis of root causes by repeating 5 why-questions \\
\hline The Deming Cycle (PDCA) & $\begin{array}{l}\text { The cycling process of decision-making including planning, doing, } \\
\text { checking, acting }\end{array}$ \\
\hline
\end{tabular}

Source: compiled by the authors.

The first six steps necessary while implementing lean management principles by government authorities were formulated by S. Craite:

- defining the vision of an organization by the employees enjoying their work and fulfilling their activities efficiently and with the orientation at customers;

- the process involving all employees including the leadership, and the allocation of resources for developing the process;

- standard setting and control;

- setting out the objectives and the stages of achieving them;

- comprehensive support of changes, both in the whole organisation and within each of its departments and processes;

- adherence to the plan and determination [8].

In lean management, each inhabitant is considered as a consumer of services provided by local authorities and organizations. The activities of local authorities and organizations are considered through the degree of meeting the needs of local population. In this regard, additional functions and the introduction of new kinds of service become the lifeblood of the success of local authorities and organizations.

In Russia, the Republic of Tatarstan has pioneered in implementing lean management principles at the municipal level. In particular, the Almetyevsky municipal raion and the city of Almetyevsk have been realizing the program 'Lean city' [9]. Lean production technologies have been implemented by the municipal administration of Naberezhnye Chelny [10]. The Concept 'Lean Region' (the system of interaction between subjects of lean production, including municipal areas commonly and consistently using the principles of lean management in their activities) has been worked out in the Khanty-Mansi Autonomous Area [11]. The Concept 'Lean production' has also been realized in municipal areas of the Ulyanovsk Region and the Belgorod Region so far.

The research enabled to state that the introduction of lean management at the municipal level involves barriers of two kinds: general (also typical for the business sector) and specific ones (the problems of government bodies). General barriers are: insufficient motivation of leadership; low competence of the administration; organizational culture forcing employees think that time spent on improving processes is less valuable than that spent on activities; low qualification of employees; union regulations; a lot of undocumented procedures. General barriers are: specific technologies of managing municipal employees, a peculiar attitude of municipal employees to stability; lack of direct relationship between government bodies incomes and created by them added value; electoral cycles and post-occupancy limits; competing groups of political interests; legislative control.

The research showed that requirements of international standards are applicable to State and local government bodies. High level of municipal services may be achieved by:

- developing and introducing branch standards of service delivery by local government bodies;

- implementing international and Russian quality standards and transparency principles of local government bodies activities;

- working out an organizational plan representing goals, objectives and ways of their achievement in each local government body;

- developing the system of internal and external audit for controlling the standards including the ones for providing municipal services.

\section{Conclusion}

A successful adaptation of lean production principles should consider specific processes in municipal management: the importance of information, great number of information transfer stages, cross-cutting nature of processes, significant variability of tasks, lack of clear motivation for accelerating service provision, implicit gains and losses, numerous check-outs, low quality of communication between departments and conservatism towards changes. The implementation of this concept in municipal management should involve the emphasis on waste typical for offices and the optimization of processes of administrative service provision and supporting processes.

The implementation of lean principles by local authorities will increase the efficiency of municipal management, improve the quality of municipal services, eliminate waste of resources, raise municipal employees of a new kind $-\mathrm{a}$ creative ones, which will result in improving the life quality of population. 


\section{Acknowledgments}

This paper is an output of the science project No. 17-02-00340 "Innovative Development of Russian Regions in the Conditions of Sanctions: Impact Assessments, Differentiation and Opportunities for Advanced Development 2017 2018 " of the Russian Foundation for Basic Research.

\section{References}

1. N.V. Voroshilov, Effectiveness of municipal administration: the essence and approaches to its evaluation. Problems of Development of the Territory, 3(77), 143-159. URL: http://pdt.vscc.ac.ru/article/1265. Accessed: 21.10.2018 (2015). [in Rus.].

2. J.P. Womack, D.T. Jones, Lean thinking: Banish waste and create wealth for your corporation. New York, NY: Simon and Schuster (1996).

3. John F. Krafcik, Triumph of the lean production system. MIT Sloan Management Review, 30(1), 41-52. URL: https://www.lean.org/downloads/MITSloan.pdf. Accessed: 21.10.2018 (1988).

4. J.P. Womack, D.T. Jones, D. Roos, The machine that changed the world. New York, N.Y.: Free Press (1990).

5. A.S. Tsarenko, Lean state: Prospects of using lean technologies in state administration in Russia and abroad. E-journal "Public Administration", $\quad$ 45, $\quad$ 74-109. URL: journal.spa.msu.ru/uploads/vestnik/2014/vipusk_45._avgust_2014_g./problemi_upravlenija_teorija_i_praktika/tsarenko. pdf. Accessed: 21.10.2018 (2014). [in Rus.].

6. A.I. Mukharlyamova, T.A Ovcharova, The prospects of lean production development in Russia and current state of affairs. International Scientific Journal "Innovative Science", 11-1, 114-116. URL: https://cyberleninka.ru/article/n/perspektivy-razvitiya-berezhlivogo-proizvodstva-v-rossii-i-tekuschee-sostoyaniedel. Accessed: 21.10.2018 (2016). [in Rus.].

7. Yu.P. Klochkov, Lean production: a concept, principles, mechanisms. Engineering Journal of Don, 2, 429-437. URL: https://cyberleninka.ru/article/n/berezhlivoe-proizvodstvo-ponyatiya-printsipy-mehanizmy. Accessed: 21.10 .2018 (2012). [in Rus.].

8. L.N. Albastova, I.A. Khasheva, Lean production technology as a factor of increasing efficiency of government bodies. State and Municipal Management. Scholar Notes, 2, 85-96. URL: https://cyberleninka.ru/article/n/tehnologiya-berezhlivogo-proizvodstva-kak-faktor-povysheniya-effektivnostideyatelnosti-organov-vlasti. Accessed: 21.10.2018 (2014). [in Rus.].

9. D.N. Gusarov, On the issue of increasing the efficiency of municipal units: Experience of Al'metyevsk. Actual Problems of Economics and Law, 2, 70-74. Retrieved from: https://cyberleninka.ru/article/n/k-voprosampovysheniya-effektivnosti-munitsipalnyh-obrazovaniy-opyt-almetievska. Accessed: 01.12.2018 (2013). [in Rus.].

10. N.A. Kropotova, R.I. Belyaev, I.A. Shigin, Lean production - a basis for sustainable development. Budget, 7. URL: http://bujet.ru/article/303688.php. Accessed: 01.12.2018 (2016). [in Rus.].

11. Decree "O Kontseptsii 'Berezhlivyy region' v Khanty-Mansiyskom avtonomnom okruge - Yugre" from 19.08.2016 N 455-rp. Retrieved from: https://leanregion.admhmao.ru/kontseptsiya/760256/rasporyazheniya-pravitelstva-khantymansiyskogo-avtonomnogo-okruga-yugry-ot-19-avgusta-2016-g-455-rp. Accessed: 01.12.2018 (2016). [in Rus.]. 